\title{
The Determinants of Capital Structure: Evidence from Egyptian Listed Firms
}

\author{
Abdel Rahman Hussein, Ahmed Sakr, Alaa Abdel Barie \\ College of Management \& Technology, Arab Academy for Science \& Technology, Alexandria, Egypt \\ Email: abdelrahmanhussien@hotmail.com
}

How to cite this paper: Hussein, A.R., Sakr, A. and Barie, A.A. (2019) The Determinants of Capital Structure: Evidence from Egyptian Listed Firms. Open Access Library Journal, 6: e5671. https://doi.org/10.4236/oalib.1105671

Received: August 7, 2019

Accepted: August 25, 2019

Published: August 28, 2019

Copyright () 2019 by author(s) and Open Access Library Inc.

This work is licensed under the Creative Commons Attribution International License (CC BY 4.0).

http://creativecommons.org/licenses/by/4.0/

\section{(c) (7) Open Access}

\begin{abstract}
In the finance literature, there has been an increasing interest on what are the determinants of capital structure of firms; the determinants of capital structure of more developed economies are the main concern of the existing literature. This proposal aims to expand this literature by ascertaining the determinants of capital structure in an emerging economy like Egypt. In this research, regression analysis is used to test the relationship between a defined set of determinants and capital structure decisions.
\end{abstract}

\section{Subject Areas}

Accounting, Business Analysis, Business Finance and Investment, Economics

\section{Keywords}

Ownership Structure, Capital Structure, Egypt

\section{Introduction}

Firm's capital structure is one of the essential and complicated areas of corporate strategy and financial decision making. It indicates the mixture of debt, equity, and other sources of funds a firm need to finance its operations.

Modigliani \& Miller (1958) [1], as the pioneers of the study of the determinants of firm's capital structure provided the foundation for an understanding of the distinctness between leveraged and unleveraged companies values, which increased the interest on the study of capital structure analysis and the key factors influencing financing decisions. After Modigliani \& Miller defined the founding base of the theory the prominence shifted toward analyzing the factors that affect the capital structure under dissimilar context and the purpose of the research has moved facing clarifying the logic firms behave in a specific fashion with respect to their financing, instead of trying to determine a one-size-fits-all 
solution.

Several theories have emerged to explain the mix of security and financing sources of a firm.

Indeed, the financing preference of companies is perhaps, the most investigated subject in finance field in the previous decades after the generative work of Modigliani \& Miller (1958) [1] highlighting the argument of the association between a company's financing choice and its value and however there is no generally acknowledged theory of the debt-equity choice, there are assorted hypotheses that have surfaced in the last two decades explaining firms' capital structure. The most important theories are Trade-off theory, Pecking order theory, Agency theory, Signalling Theory and Market Timing Theory.

\section{Literature Review and the Hypotheses}

Capital Structure is described as the mix of debt and equity, or hybrid securities a firm uses to finance its capital expenditures and day to day operations. In simple terms, it is defined as the leverage ratio, Capital structure and its result on the company's value was initially introduced by the hypothesis of capital structure introduced in 1958, when Franco Modigliani and Merton Miller [1] projected the M\&M irrelevance proposition. They simulated that, in a capital market with perfect information, no bankruptcy costs and taxes, the firm's financial leverage is irrelevant to its value, their theory rationalised that the company value is not effected whether the company is financed through debt or equity issuance, or a combination of the two, where the reason is that if there are any changes in the debt to equity ratio, the company's cash flow will stay unchanged, also they debated that all companies have equal opportunities to acquire loans at the same rate [1]. Modigliani and Miller (1958) advocate that, in a friction less world, there is no distinctness between equity and debt financing regarding to the value of the company and thus, financing decisions add no value and are therefore of no concern to the manager.

Several theories of capital structure evolved from Modigliani and Miller's model, and they can be categorized into two groups: The first are those which recognize the existence of an optimal level of debt, such as trade-off theoryKraus \& Litzenberger (1973) [2], the agency theory Jensen \& Meckling (1976) [3], and the free cash flow theory Jensen (1986) [4]. The second does not recognize any optimal amount of debt and includes the pecking order theory Myers \& Majluf (1984) [5] \& the equity market timing theory by Baker \& Wurgler (2002) [6].

Miller's revision [7] from 1977 in which he takes into consideration the personal income taxes ends with the finding that the differential tax impact on debt and equity holders diminish the formerly praised interest tax shield, as the tax shield stand was further backed by De Angelo and Masulis (1980) [8] through the incorporation of non-debt tax protection and as a result, over the course of two decades, the capital structure theory was embellished with a group of useful insights, but it barley achieved any progress from the early positions concerning 
the resolution of the optimal capital structure riddle Myers (1984) [9]. The pecking order theory declared by Myers (1984) [9] and explained with in depth detail in Myers and Majluf (1984) [5] asserts that rather than addressing a certain debt-equity ratio, the managers pursue an array of steps aiming to lessen the negative results of information asymmetries. Greater leverage can also aid as a protective mechanism to curb managerial discretion on free cash flows Grossman and Hart (1982) [10], Jensen (1986) [4], Baker and Wurgler (2002) [6] associate the capital structure riddle to the market timing theory and affirm that the capital structure is an outcome of the previous decisions of the companies to issue equity in periods with the highest market valuations of their shares.

\subsection{Managerial Ownership and Firm Capital Structure}

Studies on ownership emerge with the seminal work that highlighted the dissolution between ownership as a principle trait of the contemporary corporation's control, emphasizing the potential of distinction between manager's and owner's objective and debating that this segregation should develop opportunity for managers to seize firm resources for their benefits, moreover Demsetz (1983) [11] and Fama \& Jensen (1983) [12] stated that there may be an inverse result of managerial equity ownership on agency problems, such as managerial opportunism, where Jensen (1986) [4] defined the principal-agent relationship as "a conflicting interest's filled relation" and claimed that management is motivated to grow the company beyond its optimal size, as with the company size increase the resources under managers control increase which may add up to their power.

Myers \& Majluf (1984) [5] stated that managers controlling the company on behalf of its shareholders have access to more timely and accurate information related to the company, as a result pecking order theory states that an order in financing decisions is followed by managers, like primarily utilizing internal funds available "retained earnings", then debt issuance and lastly equity issuance. Furthermore, Grossman and Hart (1982) [10] stated that managers of near to zero debt companies don't have a powerful incentive for profit maximization, because there will be less pressure from creditor monitoring or potential bankruptcy.

Friend \& Lang (1988) [13] suggested a negative correlation between leverage and managers share holds, mirroring the higher non diversifiable risk of acquire debt for managers that for public investors to preserve low leverage ratio, while Bathala et al. (1994) [14], stated a negative relation between a firm's debt usage and managerial stock ownership and its institutional ownership.

Berger et al. (1997) [15] examined the effects of empowered managers on capital structure in American public firms and stated that managing director's direct stock ownership has a positive relation with the company's leverage, which shows the conflict of interests between managers and shareholders with the hike of financial incentives, Short et al. (2002) [16] also suggested a direct correlation 
between firm leverage and management ownership. Furthermore, Al-Fayoumi \& Abuzayed (2009) [17] state a negative relation between managerial insiders and firm's leverage, indicating that management utilize less debt to avoid the stress related to immense debt capital, while Friend and Lang (1988) [13] figured that companies with high ownership concentration acquire more debts than firms with less concentration. Farooq (2014) [18] argued that concentration of ownership leads to less leverage ratio as measured by debt to equity, debt to total asset and debt to total value ratios.

H1: There is a positive relationship between Managerial ownership and firm's leverage ratio

\subsection{Foreign Ownership and Firm Capital Structure}

Most research in this area conclude a negative relationship between foreign ownership and leverage, except for the research of Zou \& Xiao (2006) [19], Gurunlu \& Gursoy (2010) [20], while the practical research on the association between ownership and firms leverage has been administrated using data composed from industrialized economies, where theories by Kester (1986) [21] and King \& Santor (2008) [22] of ownership and capital structure highlights the role of debt in diminishing agency problems between shareholders and manager. According to Chaganti \& Damanpour (1991) [23] the amount of foreign institutional stockholdings affects a firm's capital structure significantly and the insider and family institutional owners' shareholdings balance the association between foreign stockholders and capital structure. Gurunlu \& Gursoy (2010) [20] constructed a study on the effects of foreign ownership on the leverage of non financial firms listed in the stock exchange in Istanbul over a time frame of ten years and concluded that foreign ownership has a significant inverse relation to long term debts, moreover the influence of foreign ownership on firms leverage was tested in emerging economies and a significantly inversely relation to total debts based on the book value of assets and market value of equity was found, showing definitively that firms with foreign shareholders rely less on external cash resources.

Hussain \& Nivorozhkin (1997) [24] confirm that a noticeably higher debt ratio is exerted from foreign owned firms than their domestic owned counterparts in the host nation, where the research of Li et al. (2009) [25] found a negative correlation between foreign ownership and all examined leverage measures (short-term debt, long-term debt and book leverage) because firms with foreign ownership are subjected to less corporate tax rates than ones with domestic ownership. FurthermoreMoon (2001) [26] found that foreign ownership assist to curb the manager's overinvestment problem or lower the agency conflict between shareholders and managers and as a result foreign ownership and firm's leverage might serve as replacements in disciplining managerial self interest.

$\mathrm{H} 2$ : There is a positive relationship between foreign ownership and firm's leverage ratio 


\subsection{Block Holders Ownership and Firm Capital Structure}

A lot of prior studies proposed that abundant ownership affects capital structure decisions through controlling the managers and shareholders conflicts. Nevertheless empirical studies of this relationship have not been persistent and clear yet. Pound \& Zeckhauser (1990) [27] reported that the corporate governance quality and management efficiency can be enhanced through block holders, as they debate that the existence of block holders can reflect a positive signal to shareholders that mangers will operate in their best interest and so lowering the equity's agency costs by curtailing the collusions between shareholders \& management moreover alleviating the management usage of debts as a signal. On the other hand Pound (1988) [27] suggested that these block holders could conspire with inside management opposing to scattered shareholders best interest, in case of which firms' leverage will be inversely related to block holder's ownership. While Stulz (1988) [28] found that companies with dominant shareholders might exert greater financial leverage, as it raise their voting control in light of a given level of equity investment, lower hostile takeover risk and hike the takeover premium entrenched in the stock price.

Shleifer \& Vishny (1986) [29], Wiwattanakantang (1999) [30] stated that block holders have an effective role in a firm's performance as large investors control the company, cut or replace managers if the company's performance is poor, and as a result large ownership can work as a substitute for debt finance to increase the supervising of managers. Whereas Friend \& Lang (1988) [13] figured that companies with large block holders ownership have more levels of debts than those with little block ownership, as they stated that high block holders ownership might have more monitoring of managers, and as a result leading managers to issue debts more than their desire, where it is assumed to be below the optimal ratio to avert bankruptcy possibility.

Pound (1988) [27] stated that block holders might have negative and positive effects, as institutional investors can hike up the managers monitoring more than the individual investors, nonetheless a negative effect can take place if they connive with managers against the interest of other shareholders. Brailsford, Oliver \& Pua (2002) [31] examining 500 Australian listed firms from 1989 to 1995, found abetting evidence of the direct correlation between block ownership and leverage, an outcome explained the monitoring role, which endorse that block shareholders have withstanding motivation for managers monitoring and so lowering agency conflicts and managerial opportunism. FurthermoreBrailsford et al. (2002) [31] stated that the allocation of equity ownership between internal corporate managers and block holders might have a strong relation with leverage, suggesting that the correlation between block holders and capital structure differ across the various layers of managerial share holding. Fosberg (2004) [32] stated that block holders' ownership can result in better firm monitoring and so higher debt utilization than insider management's ambition (Table 1). 
Table 1. Variables definition and measurement.

\begin{tabular}{llll}
\hline Variable & Code & Measurement & Reference \\
\hline $\begin{array}{l}\text { Managerial } \\
\text { Ownership }\end{array}$ & MOWN & $\begin{array}{l}\text { The amount of shares owned by } \\
\text { individuals with managerial roles } \\
\text { in the company as a measure of } \\
\text { ownership }\end{array}$ & $\begin{array}{l}\text { Shin-Ping \& Tsung-Hsien, 2007 } \\
{[33]} \\
\text { Li, Yue and Zhao, 2009 [25] }\end{array}$ \\
$\begin{array}{l}\text { Foreign } \\
\text { Ownership }\end{array}$ & FOWN & $\begin{array}{l}\text { The amount of shares owned by } \\
\text { foreign institutions as a measure } \\
\text { of ownership }\end{array}$ & $\begin{array}{l}\text { Soliman, 2013 [34] and Bennde- } \\
\text { sen \& Wolfenzon (2000) [35] }\end{array}$ \\
$\begin{array}{l}\text { Block holders } \\
\text { Ownership }\end{array}$ & BOWN & $\begin{array}{l}\text { The amount of shares owned by } \\
\text { individual or institutional } \\
\text { block-holders as a measure of } \\
\text { ownership }\end{array}$ & Soliman, 2013 [34] \\
\hline
\end{tabular}

H3: There is a positive relationship between Block holders ownership and firm's leverage ratio

\section{Research Methodology}

\subsection{Data Collection and Sample Selection}

The sample consists of 50 most active companies on Egyptian stock exchange, which are 50 firms belong to 12 sectors, which are Food and Beverage, Chemicals, Basic Resources, Construction and Materials, Media and Telecommunications, etc. In this study the researcher excludes the banking and insurance sectors because the characteristics of these firms are different from the firms in other industrial sectors in terms of specialized in nature and were subject to different regulations and accounting rules. The final sample consists of 48 firms.

This paper uses secondary data only which is collected from the latest available financial statements of the firms. This study employed annual data from 2012 to 2017. The researcher depends on the Egypt exchange disclosure book and official Egypt stock exchange web page to collect data.

\subsection{Variables and Measurement}

The variables applied in this study can be divided into two main types which are; the dependent and independent variables.

\subsubsection{Dependent Variable}

The dependent variable for this study is the capital structure decisions of firms listed in the Egyptian market. The performance will be measured by the financial leverage the most commonly used measures in the former ownership literatures.

\subsubsection{Independent Variables}

The independent variables employed in this study are factors identified in prior research as influences performance, either positively or negatively. There are three independent variables that will be measured. These are managerial ownership, foreign ownership and block holder ownership.

This research tried to look at the possibility of the relationship between de- 
pendent variable and independent variables. The relationship between dependent variable and independent variables is as shown in Figure 1.

\subsubsection{Control Variables}

The control variables were selected in accordance to similar studies made on this topic (e.g. Pound 1988 [27]; Abor 2007 [37]; and Anderson et al. 2004 [38]). The selected variables are firm profitability and industry classification. These variables are selected because they have shown to have simultaneous effect onboard attribute, ownership and leverage.

Table 2 demonstrates a summary for all the variables including the dependent, independent and control variables of the study.

\subsection{Research Model}

To test the hypothesis common effect model in panel data analysis has been used.

$$
C i, t=\beta 0+\beta 1 \mathrm{MOWN}+\beta 2 \mathrm{FOWN}+\beta 3 \mathrm{BOWN}+e
$$

where $C$ is Capital structure of firm $i$ in period $t$ represented by financial leverage, MOWN, Managerial ownership; FOWN, Foreign ownership; BOWN, Block holders ownership; $\beta 0$ is the intercept; $\beta$ is the regression coefficient and $\varepsilon$ is the composite error terms.

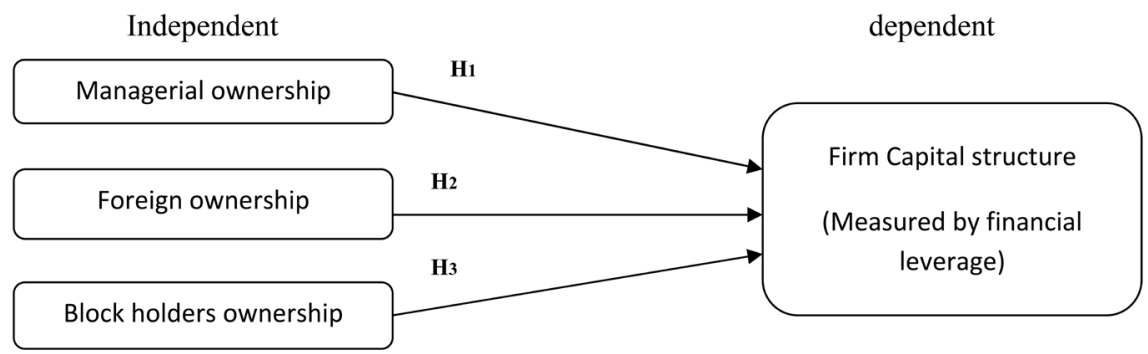

Figure 1. Research conceptual framework.

Table 2. Summary of variables.

\begin{tabular}{ll}
\hline Variable & Measures \\
\hline Capital Structure measure: & Leverage = Total liabilities/Shareholders Equity \\
\hline Financial leverage (LEV) & The percentage of total shares held by members of the board \\
Ownership Variables: & of directors divided by total ordinary shares outstanding. \\
Managerial Ownership & $\begin{array}{l}\text { The percentage of total shares held by foreign investors } \\
\text { divided by total ordinary shares outstanding. }\end{array}$ \\
Foreign Ownership & $\begin{array}{l}\text { The percentage of equity owned by persons and institutions } \\
\text { holding5\% or more of the company's equity. }\end{array}$ \\
Block holders Ownership & Earnings before tax and interest over total assets book value \\
Control Variables: & $\begin{array}{l}\text { Measure of the impact of different industries in modelling } \\
\text { firms' capital structure }\end{array}$ \\
Firm profitability &
\end{tabular}




\section{Findings and Analysis}

\subsection{Descriptive Analysis}

Table 3 summarizes the Minimum, Maximum, Mean and Standard Deviations for the research variables.

\subsection{Testing the Hypothesis: Relationship between Ownership Structure and Capital Structure}

This hypothesis tests the relationship between the structure of Ownership and company's Leverage. The below sections respond to the research hypothesis using correlation and regression analysis;

\section{Testing the Relation between Ownership Structure and Firm Leverage}

Table 4 demonstrates the correlation matrix for the relationship between Managerial Ownership and Firm Leverage. It showed that there is an insignificant association between Managerial Ownership and Firm Leverage, as the corresponding $\mathrm{P}$-value is more than 0.05 .

Table 5 demonstrates the regression model for the effect of Managerial Ownership on Firm Leverage. It resulted that there is an insignificant effect of Managerial Ownership on Firm Leverage, as the corresponding P-value is above 0.05.

Therefore, the equation could be formulated as follows:

Firm Leverage $=0.750046-0.655114$ * Managerial Ownership

Thus, the second hypothesis that states a significant association between Managerial Ownership and Firm Leverage is not supported.

Table 6 demonstrates the correlation matrix for the relationship between Foreign Ownership and Firm Leverage. It resulted that there is an insignificant association between Foreign Ownership and Firm Leverage, as the corresponding $\mathrm{P}$-value is more than 0.05 .

Table 7 demonstrates the regression model for the effect of Foreign Ownership on Firm Leverage. It was found that there is an insignificant effect of Foreign Ownership on Firm Leverage, as the corresponding P-value is more than 0.05 .

Therefore, the equation could be formulated as follows:

$$
\text { Firm Leverage }=0.7969-0.333800 \text { * Foreign Ownership }
$$

Thus, the second hypothesis that there is a significant correlation between Foreign Ownership and Firm Leverage is not supported.

Table 8 demonstrates the correlation matrix for the relationship between Block holder and Firm Leverage. It resulted that there is an insignificant correlation between Block holder and Firm Leverage, as the corresponding P-value is more than 0.05 .

Table 9 demonstrates the regression model for the effect of Block holder Ownership on Firm Leverage. Resulted that there is an insignificant effect of Block holder on Firm Leverage, as the corresponding P-value is more than 0.05.

Therefore, the equation could be formulated as follows: 
Firm Leverage $=1.1578-0.31297 *$ Block holders

Thus, the second hypothesis that there is a significant relationship between Block holders and Firm Leverage is not supported.

Table 10 demonstrates the regression model for the effect of Ownership Structure; Managerial Ownership, Foreign Ownership, and Block holder on Firm Leverage. It resulted that there is a problem of multicollinearity in foreign ownership. After deleting, It was observed that there is an insignificant effect of Managerial Ownership, and Block holder on Firm Leverage, as the corresponding P-values are more than 0.05 .

Therefore, the equation could be formulated as follows:

$$
\text { Firm Leverage }=1.9739-1.7721-1.137350 * \text { Ownership Structure }
$$

Thus, the second hypothesis that there is a significant correlation between Ownership Structure and Firm Leverage is Not supported.

Table 3. Minimum, maximum, mean and standard deviations for the research variables.

\begin{tabular}{ccccc}
\hline & Minimum & Maximum & Mean & Std. Deviation \\
\hline Managerial Ownership & 0.00 & 0.92 & 0.1630 & 0.26093 \\
Foreign Ownership & 0.00 & 1.00 & 0.5984 & 0.22071 \\
Blockholder & 0.00 & 1.00 & 0.5984 & 0.22071 \\
Firm Profit & $-2,003,056,956.00$ & $9,440,788,836.00942,983,546.6912$ & $1,747,128,252.14105$ \\
Firm Leverage & 0.00 & 27.36 & 0.5482 & 1.76779 \\
\hline
\end{tabular}

*Sample size $(\mathrm{n})=48$ firm year observations during the years 2011-2017, Based on the availability of data.

Table 4. Correlation matrix between managerial ownership and firm leverage.

\begin{tabular}{cccc}
\hline & MANAGERIAL_OWNERSHIP & FIRM_LEVERAGE & p-value \\
\hline MANAGERIAL_OWNERSHIP & 1.000000 & -0.074153 & 0.341 \\
FIRM_LEVERAGE & -0.074153 & 1.000000 & \\
\hline
\end{tabular}

Table 5. Regression model of managerial ownership on firm leverage.

\begin{tabular}{ccccc}
\hline \multicolumn{4}{c}{ Dependent Variable: FIRM_LEVERAGE } & \\
\hline Variable & Coefficient & Std. Error & t-Statistic & Prob. \\
\hline MANAGERIAL_OWNERSHIP & -0.655114 & 0.685881 & -0.955142 & 0.3409 \\
C & 0.750046 & 0.210550 & 3.562323 & 0.0005 \\
Adjusted R-squared & 0.005499 & Mean dependent var & 0.643284 \\
S.E. of regression & -0.000529 & S.D. dependent var & 2.305211 \\
Sum squared resid & 2.305820 & Akaike info criterion & 4.520654 \\
Log likelihood & 877.2730 & Schwarz criterion & 4.557995 \\
F-statistic & -375.4746 & Hannan-Quinn criter. & 4.535810 \\
Prob(F-statistic) & 0.912297 & Durbin-Watson stat & 2.511023
\end{tabular}


Table 6. Correlation matrix between foreign ownership and firm leverage.

\begin{tabular}{cccc}
\hline & FOREIGN_OWNERSHIP & FIRM_LEVERAGE & p-value \\
\hline FOREIGN_OWNERSHIP & 1.000000 & -0.072537 & \\
FIRM_LEVERAGE & -0.072537 & 1.000000 & 0.230 \\
\hline
\end{tabular}

Table 7. Regression model of foreign ownership on firm leverage.

\begin{tabular}{ccccc}
\hline \multicolumn{4}{c}{ Dependent Variable: FIRM_LEVERAGE } & \\
\hline Variable & Coefficient & Std. Error & t-Statistic & Prob. \\
\hline FOREIGN_OWNERSHIP & -0.333800 & 0.270919 & -1.232103 & 0.2189 \\
C & 0.796914 & 0.226215 & 3.522819 & 0.0005 \\
R-squared & 0.005262 & Mean dependent var & 0.549438 \\
Adjusted R-squared & 0.001796 & S.D. dependent var & 1.770728 \\
S.E. of regression & 1.769137 & Akaike info criterion & 3.985757 \\
Sum squared resid & 898.2658 & Schwarz criterion & 4.011130 \\
Log likelihood & -573.9419 & Hannan-Quinn criter. & 3.995924 \\
F-statistic & 1.518079 & Durbin-Watson stat & 1.767062 \\
Prob(F-statistic) & 0.218919 & & \\
\hline
\end{tabular}

Table 8. Correlation matrix between block holder and firm leverage.

\begin{tabular}{cccc}
\hline & BLOCK_HOLDER & FIRM_LEVERAGE & p-value \\
\hline BLOCK_HOLDER & 1.000000 & -0.019921 & \multirow{2}{*}{0.924} \\
FIRM_LEVERAGE & -0.019921 & 1.000000 & \\
\hline
\end{tabular}

Table 9. Regression model of block holders on firm leverage.

\begin{tabular}{|c|c|c|c|c|}
\hline \multicolumn{5}{|c|}{ Dependent Variable: FIRM_LEVERAGE } \\
\hline Variable & Coefficient & Std. Error & $\mathrm{t}$-Statistic & Prob. \\
\hline BLOCK_HOLDER & -0.312972 & 1.790072 & -0.174838 & 0.8617 \\
\hline $\mathrm{C}$ & 1.157848 & 1.148083 & 1.008505 & 0.3164 \\
\hline R-squared & 0.000397 & \multicolumn{2}{|c|}{ Mean dependent var } & 0.968191 \\
\hline Adjusted R-squared & -0.012585 & \multicolumn{2}{|c|}{ S.D. dependent var } & 3.321287 \\
\hline S.E. of regression & 3.342121 & \multicolumn{2}{|c|}{ Akaike info criterion } & 5.276079 \\
\hline Sum squared resid & 860.0725 & \multicolumn{2}{|c|}{ Schwarz criterion } & 5.336065 \\
\hline Log likelihood & -206.4051 & \multicolumn{2}{|c|}{ Hannan-Quinn criter. } & 5.300111 \\
\hline F-statistic & 0.030568 & \multicolumn{2}{|c|}{ Durbin-Watson stat } & 2.507651 \\
\hline Prob(F-statistic) & 0.861666 & & & \\
\hline
\end{tabular}


Table 10. Regression model of ownership structure on firm leverage.

\begin{tabular}{ccccc}
\hline \multicolumn{5}{c}{ Dependent Variable: FIRM_LEVERAGE } \\
\hline Variable & Coefficient & Std. Error & t-Statistic & Prob. \\
\hline MANAGERIAL_OWNERSHIP & -1.772151 & 1.407991 & -1.258639 & 0.2120 \\
BLOCK_HOLDER & -1.137350 & 1.899795 & -0.598670 & 0.5512 \\
C & 1.973972 & 1.314769 & 1.501383 & 0.1374 \\
R-squared & 0.020807 & Mean dependent var & 0.968191 \\
Adjusted R-squared & -0.004961 & S.D. dependent var & 3.321287 \\
S.E. of regression & 3.329515 & Akaike info criterion & 5.280765 \\
Sum squared resid & 842.5109 & Schwarz criterion & 5.370744 \\
Log likelihood & -205.5902 & Hannan-Quinn criter. & 5.316814 \\
F-statistic & 0.807486 & Durbin-Watson stat & 2.564301 \\
Prob(F-statistic) & 0.449767 & & \\
\hline
\end{tabular}

\section{Conclusions}

In fact it is crucial nowadays to explore the different factors that affect the capital structure. Actually the aim of the paper is to develop and investigate the determinants affecting capital structure framework, in addition to identify the effects of each of those factors on capital structure. Consequently the research objectives could be stated as follows: Ownership structure (Managerial, Foreign and Block holders) had a relationship with the corporate choice of capital structure. Second, the aim of this research was to examine the effects of this combination of variables on the capital structure decisions.

Furthermore this research was done to identify the factors affecting capital structure in the Egyptian market. The consequence of ownership structure on capital structure was examined by the application on quantitative approach suggested in this research. This approach was handled by investigating the secondary data collected from Egypt Stock Exchange and the results found was displayed before previously. The quantitative study was applied on the top $50 \mathrm{com}$ panies listed in Egypt Stock Exchange through the period from 2012 to 2017. Then the studied sample was considered to be representative to firms in Egypt and so the outcomes of the research might be generalized to all firms in Egypt as well.

Considering the analysis of the hypothesis "Testing the Relation between Ownership Structure and Firm Leverage" by using the correlation, results stated that there is an insignificant correlation between Managerial Ownership and Firm Leverage, as the corresponding P-value is above 0.05 . Furthermore, by using the correlation, it was found that there is an insignificant correlation between Foreign Ownership and Firm Leverage, as the corresponding P-value is above 0.05 . Moreover, by using the correlation, it was found that there is an insignificant correlation between Block holder and Firm Leverage, as the corres- 
ponding P-value is more than 0.05. Thus, the first sub hypothesis of the first hypothesis was not supported.

The research results were not supported by Bajaj et al. (1998) [39] as a positive relation between ownership and leverage ratio was proved, which implies the correlation between ownership and financial structures of a company. On the other hand, the result agreed with Friend and Lang, 1988 [13] who stated a negative relation between management shareholding and firm's leverage, mirroring the higher undiversifiable debt risk to managers than to general investors to preserve less leverage ratio. Moreover, Firth (1995) [40], Bathala et al. (1994) [14], Jensen et al. (1992) [41], and Hardjopranoto (2006) [42] also state an inverse association between ownership and leverage.

Actually the research findings are severely affected by the economic, governmental and political issues in Egypt as a consequence of the revolutions that spoiled the economy in Egypt and accordingly the firms are negatively affected during the course under study.

Despite the fact that this result might be affected by the economic and political issues, by testing the full model of for the effect of, Managerial Ownership, Foreign ownership and Block holder on Firm Leverage. It resulted that there is an insignificant effect of Managerial Ownership, Foreign ownership and Block holder ownership on Firm Leverage, as the corresponding P-values are more than 0.05. By testing the full model for the effects of Managerial Ownership, Foreign ownership and Block holder ownership on Short-Term Debt; it was found that there is an insignificant effect on Short-Term Debt, as the corresponding P-values are more than 0.05 . Moreover, by testing the model for the effect of Managerial Ownership, Foreign ownership and Block holder ownership on Short-Term Debt, it was found that there is an insignificant effect on Long-Term Debt, as the corresponding P-values are more than 0.05 .

\section{Conflicts of Interest}

The authors declare no conflicts of interest regarding the publication of this paper.

\section{References}

[1] Modigliani, F. and Miller, M.H. (1958) The Cost of Capital, Corporation Finance and the Theory of Investment. The American Economic Review, 48, 261-297.

[2] Kraus, A. and Litzenberger, R.H. (1973) A State-Preference Model of Optimal Financial Leverage. The Journal of Finance, 28, 911-922. https://doi.org/10.1111/j.1540-6261.1973.tb01415.x

[3] Jensen, M.C. and Meckling, W.H. (1976) Theory of the Firm: Managerial Behavior, Agency Costs and Ownership Structure. Journal of Financial Economics, 3, 305-360. https://doi.org/10.1016/0304-405X(76)90026-X

[4] Jensen, M.C. (1986) Agency Costs of Free Cash Flow, Corporate Finance, and Takeovers. The American Economic Review, 76, 323-329.

[5] Myers, S.C. and Majluf, N.S. (1984) Corporate Financing and Investment Decisions 
When Firms Have Information That Investors Do Not Have. Journal of Financial Economics, 13, 187-221. https://doi.org/10.1016/0304-405X(84)90023-0

[6] Baker, M. and Wurgler, J. (2002) Market Timing and Capital Structure. The Journal of Finance, 57, 1-32. https://doi.org/10.1111/1540-6261.00414

[7] Miller, M.H. (1977) Debt and Taxes. The Journal of Finance, 32, 261-275. https://doi.org/10.1111/j.1540-6261.1977.tb03267.x

[8] DeAngelo, H. and Masulis, R.W. (1980) Optimal Capital Structure under Corporate and Personal Taxation. Journal of Financial Economics, 8, 3-29. https://doi.org/10.1016/0304-405X(80)90019-7

[9] Myers, S.C. (1984) The Capital Structure Puzzle. The Journal of Finance, 39, 574-592. https://doi.org/10.1111/j.1540-6261.1984.tb03646.x

[10] Grossman, S.J. and Hart, O.D. (1982) Corporate Financial Structure and Managerial Incentives. In: The Economics of Information and Uncertainty, University of Chicago Press, Chicago, 107-140.

[11] Demsetz, H. (1983) The Structure of Ownership and the Theory of the Firm. The Journal of Law and Economics, 26, 375-390. https://doi.org/10.1086/467041

[12] Fama, E.F. and Jensen, M.C. (1983) Separation of Ownership and Control. The Journal of Law and Economics, 26, 301-325. https://doi.org/10.1086/467037

[13] Friend, I. and Lang, L.H. (1988) An Empirical Test of the Impact of Managerial Self-Interest on Corporate Capital Structure. The Journal of Finance, 43, 271-281. https://doi.org/10.1111/j.1540-6261.1988.tb03938.x

[14] Bathala, C.T., Moon, K.P. and Rao, R.P. (1994) Managerial Ownership, Debt Policy, and the Impact of Institutional Holding: An Agency Perspective. Financial Management, 23, 38-50. https://doi.org/10.2307/3665620

[15] Berger, P.G., Ofek, E. and Yermack, D.L. (1997) Managerial Entrenchment and Capital Structure Decisions. The Journal of Finance, 52, 1411-1438. https://doi.org/10.1111/j.1540-6261.1997.tb01115.x

[16] Short, H., Keasey, K. and Duxbury, D. (2002) Capital Structure, Management Ownership and Large External Shareholders: A UK Analysis. International Journal of the economics of Business, 9, 375-399. https://doi.org/10.1080/1357151021000010382

[17] Al-Fayoumi, N.A. and Abuzayed, B.M. (2009) Ownership Structure and Corporate Financing. Applied Financial Economics, 19, 1975-1986. https://doi.org/10.1080/09603100903266807

[18] Farooq, O. and Satt, H. (2014) Does Analyst Following Improve Firm Performance? Evidence from the MENA Region. Corporate Ownership \& Control, 11, 157-166. https://doi.org/10.22495/cocv11i2c1p1

[19] Zou, H. and Xiao, J.Z. (2006) The Financing Behaviour of Listed Chinese Firms. The British Accounting Review, 38, 239-258.

https://doi.org/10.1016/j.bar.2006.04.008

[20] Gurunlu, M. and Gursoy, G. (2010) The Influence of Foreign Ownership on Capital Structure of Non-Financial Firms: Evidence from Istanbul Stock Exchange. IUP Journal of Corporate Governance, 9, 21-29.

[21] Kester, W.C. (1986) Capital and Ownership Structure: A Comparison of United States and Japanese Manufacturing Corporations. Financial Management, 15, 5-16. https://doi.org/10.2307/3665273

[22] King, M.R. and Santor, E. (2008) Family Values: Ownership Structure, Performance and Capital Structure of Canadian Firms. Journal of Banking \& Finance, 32, 2423-2432. https://doi.org/10.1016/j.jbankfin.2008.02.002 
[23] Chaganti, R. and Damanpour, F. (1991) Institutional Ownership, Capital Structure, and Firm Performance. Strategic Management Journal, 12, 479-491. https://doi.org/10.1002/smj.4250120702

[24] Hussain, M.Q. and Nivorozhkin, E. (1997) The Capital Structure of Listed Companies in Poland (No. 97-175). International Monetary Fund, Washington DC. https://doi.org/10.5089/9781451976342.001

[25] Li, K., Yue, H. and Zhao, L. (2009) Ownership, Institutions, and Capital Structure: Evidence from China. Journal of Comparative Economics, 37, 471-490. https://doi.org/10.1016/j.jce.2009.07.001

[26] Moon, H.C. and Roehl, T.W. (2001) Unconventional Foreign Direct Investment and the Imbalance Theory. International Business Review, 10, 197-215. https://doi.org/10.1016/S0969-5931(00)00046-9

[27] Pound, J. (1988) Proxy Contests and the Efficiency of Shareholder Oversight. Journal of Financial Economics, 20, 237-265. https://doi.org/10.1016/0304-405X(88)90046-3

[28] Stulz, R. (1988) Managerial Control of Voting Rights: Financing Policies and the Market for Corporate Control. Journal of Financial Economics, 20, 25-54. https://doi.org/10.1016/0304-405X(88)90039-6

[29] Shleifer, A. and Vishny, R.W. (1986) Large Shareholders and Corporate Control. Journal of Political Economy, 94, 461-488. https://doi.org/10.1086/261385

[30] Wiwattanakantang, Y. (1999) An Empirical Study on the Determinants of the Capital Structure of Thai Firms. Pacific-Basin Finance Journal, 7, 371-403. https://doi.org/10.1016/S0927-538X(99)00007-4

[31] Brailsford, T.J., Oliver, B.R. and Pua, S.L. (2002) On the Relation between Ownership Structure and Capital Structure. Accounting \& Finance, 42, 1-26. https://doi.org/10.1111/1467-629X.00001

[32] Fosberg, R.H. (2004) Agency Problems and Debt Financing: Leadership Structure Effects. Corporate Governance: The International Journal of Business in Society, 4, 31-38. https://doi.org/10.1108/14720700410521943

[33] Shin-Ping, L. and Tsung-Hsien, C. (2009) The Determinants of Corporate Performance: A Viewpoint from Insider Ownership and Institutional Ownership. Managerial Auditing Journal, 24, 233-247. https://doi.org/10.1108/02686900910941122

[34] Soliman, M. (2013) Firm Characteristics and the Extent of Voluntary Disclosure: The Case of Egypt. https://doi.org/10.2139/ssrn.2311005

[35] Bennedsen, M. and Wolfenzon, D. (1998) The Balance of Power in Close Corporations (No. 1998-15). University of Copenhagen, Department of Economics, Centre for Industrial Economics, København.

[36] Denis, D.J., Denis, D.K. and Sarin, A. (1997) Ownership Structure and Top Executive Turnover. Journal of Financial Economics, 45, 193-221. https://doi.org/10.1016/S0304-405X(97)00016-0

[37] Abor, J. (2007) Corporate Governance and Financing Decisions of Ghanaian Listed Firms. Corporate Governance: The International Journal of Business in Society, 7 , 83-92. https://doi.org/10.1108/14720700710727131

[38] Anderson, R.C., Mansi, S.A. and Reeb, D.M. (2004) Board Characteristics, Accounting Report Integrity and the Cost of Debt. Journal of Accounting \& Economics, 37, 315-342. https://doi.org/10.1016/j.jacceco.2004.01.004

[39] Bajaj, A. and Nidumolu, S.R. (1998) A Feedback Model to Understand Information 
System Usage. Information \& Management, 33, 213-224.

https://doi.org/10.1016/S0378-7206(98)00026-3

[40] Firth, M. (1995) The Impact of Institutional Stockholders and Managerial Interests on the Capital Structure of Firms. Managerial and Decision Economics, 16, 167-175. https://doi.org/10.1002/mde.4090160207

[41] Jensen, G.R., Solberg, D.P. and Zorn, T.S. (1992) Simultaneous Determination of Insider Ownership, Debt, and Dividend Policies. Journal of Financial and Quantitative Analysis, 27, 247-263. https://doi.org/10.2307/2331370

[42] Hardjopranoto, W. (2006) Interdependent Analysis of Leverage, Dividend, and Managerial Ownership Policies: Agencies Perspectives. Gadjah Mada International Journal of Business, 8, 179-199. https://doi.org/10.22146/gamaijb.5619 